\title{
Diagnosis and treatment of CD20 negative B cell lymphomas
}

\author{
Tasleem Katchi and Delong Liu*
}

\begin{abstract}
CD20 negative B cell non-Hodgkin lymphoma (NHL) is rare and accounts for approximately $1-2 \%$ of B cell lymphomas. CD20- negative NHL is frequently associated with extranodal involvement, atypical morphology, aggressive clinical behaviour, resistance to standard chemotherapy and poor prognosis. The most common types of these include plasmablastic lymphoma, primary effusion lymphoma, large B-cell lymphoma arising from HHV8-associated multicentric Castleman's disease, and ALK+ large B cell lymphoma. This review provides an overview of the diagnostic and treatment modalities for CD20 negative B cell NHL.
\end{abstract}

\section{Background}

CD20 is a glycosylated phosphoprotein expressed on the surface of all B cells (except early pro-B cells and plasma cells). Human CD20 molecule is encoded by the MS4A1 gene located on chromosome 11q12.2 [1, 2]. CD20 molecule is a tetra-transmembrane polypeptide with 297 amino acid residues. It plays a role in the differentiation, maturation and activation of B cells. CD20 is involved in the phosphorylation cascade of intracellular proteins by binding to Src family tyrosine kinases, such as Lyn, Fyn, and Lck. The CD20 molecule remains on the membrane of $\mathrm{B}$ cells without dissociation or internalization upon binding of CD20 antibody. CD20 expression varies in different lymphoma subtypes [3-5]. It is present from late pro-B cells through memory $B$ cells, but not on early pro-B cells, plasmablasts and plasma cells. Plasma cell differentiation of B cells results in acquisition of plasma cell markers and loss of B cell antigens including the expression of CD20. CD20 was first defined by the murine monoclonal antibody (MoAb) tositumomab [6, 7]. Rituximab, a chimeric CD20 MoAb, was later developed and approved for treatment of human B cell malignancies. Rituximab destroys B lymphoid malignancies through complementdependent cytotoxicity (CDC) and antibody-dependent cellular cytotoxicity (ADCC). The addition of rituximab, to cyclophosphamide, doxorubicin, vincristine,

* Correspondence: DELONG_LIU@NYMC.EDU

Division of Hematology \& Oncology, New York Medical College and Westchester Medical Center, Valhalla, NY 10595, USA and prednisone (CHOP) has dramatically improved the survival of patients with diffuse large B cell lymphoma (DLBCL) $[8,9]$. R-CHOP has since become the gold standard for the treatment of newly diagnosed DLBCL. In addition, rituximab has been found highly effective in a variety of $B$ cell malignancies as well as relapsed and refractory lymphomas. Through recombinant DNA technology, second- and third- generation CD20 MoAbs were developed [2]. Among these, ofatumumab and obinutuzumab have been approved for clinical treatment of B cell malignancies, such as chronic lymphoid leukemia, and follicular lymphoma [10-15].

Genetic mutations of MS4A1 leading to conformational changes in the protein have been speculated to be a molecular mechanism of the CD20 negative phenotype [16]. The loss of CD20 expression is associated with extranodal involvement, a more aggressive clinical course, loss of responsiveness to rituximab and conventional chemotherapy, leading to poor prognosis. It poses a diagnostic and therapeutic dilemma and further studies need to be undertaken to establish the standard of care in this group of patients.

\section{CD20 negative non-Hodgkin lymphomas}

The pan-B lymphocyte markers include CD19, CD20, CD79a, and PAX-5 $[2,17-19]$. Almost all B cell NHLs are positive for CD20. CD20- negative NHLs are rare with a rate of $1-2 \%$ of all B cell NHLs [20]. The most common types of these include plasmablastic lymphoma, primary effusion lymphoma, large B-cell lymphoma arising from 
HHV8-associated multicentric Castleman's disease, and ALK+ large B cell lymphoma [20, 21].

Plasmablastic lymphoma (PBL) is the most common subtype of CD20 negative DLBCL, accounting for $75 \%$ of the cases with a median survival of 12 months [22, 23]. PBL is frequently associated with HIV and/or EpsteinBarr virus (EBV) co-infection. Immunoblastic lymphoma is frequently related and can be difficult to differentiate from PBL.

Primary effusion lymphoma (PEL), as the name suggests, presents as pleural, peritoneal and/or pericardial effusion. It is associated with HIV, EBV, and human herpesvirus 8 (HHV8) co-infection and has a median survival of 9 months [24].

Large B-cell lymphoma arising from HHV8-associated multicentric Castleman disease (MCD) usually presents in the setting of HIV infection. Unlike HHV-8 associated PEL, large B-cell lymphomas arising from MCD frequently has unmutated immunoglobulin IgM and lambda-chain restriction, suggesting an origin from HHV-8- positive plasmablasts [25].

Anaplastic lymphoma kinase (ALK) -positive DLBCL is a very rare type of DLBCL [26]. Unlike ALK+ anaplastic large cell lymphoma which harbors the ALK-NPM fusion gene from $t(2 ; 5)$ translocation with favorable prognosis, ALK+ DLBCL usually has $\mathrm{t}(2 ; 17)$ (p23; q23) translocation which leads to a fusion gene of ALK-CLTC [27, 28]. Unlike the common DLBCL, ALK+ DLBCL is usually positive for $\mathrm{CD} 38$, CD138, and negative for $\mathrm{CD} 20$, CD30, and CD79a [28]. This type of lymphoma has a median survival of 20 months.

In addition to the above rare $\mathrm{CD} 20$ negative lymphomas, CD20 positive lymphoma can relapse as CD20 negative lymphoma after CD20 antibody therapy [29].

\section{Diagnosis of CD20 negative NHL}

DLBCL is identified by morphology and $\mathrm{B}$ cell biomarker analysis by immunohistochemistry and flow cytometry studies. However, CD20 negative DLBCL can pose a diagnostic dilemma. Immunohistochemical detection of CD19, CD79a and PAX-5 are the major biomarkers in establishing the diagnosis of CD20 negative B cell lymphoma. CD5 expression in DLBCL is mostly associated with Richter's transformation from a lowgrade B-cell lymphoma, but has been seen in $5 \%$ of de novo DLBCL [30]. Similarly, CD10 expression is seen in both de novo DLBCL as well as in transformed follicular lymphomas [31]. Oct-2, Bob-1, and SOX11 are frequently examined and useful for differential diagnosis and accurate classification of lymphoma diagnosis $[32,33]$. Flow cytometric analysis can reveal positivity for CD19, CD79a, CD5 and CD10 in cases of CD20 negative lymphoma.
Molecular analysis using cytogenetics or FISH (fluorescent in-situ hybridization) to detect rearrangements or translocations of Bcl-2, Bcl-6 and MYC is an important part of diagnosis. BCL-2 mutation was found frequently in human B cell lymphomas [34, 35]. Rearrangements or translocations of both BCL-2 and MYC are hallmarks of "double-hit" lymphomas which are typically more resistant to R-CHOP and portent poor prognosis. More intensive chemotherapy regimens and new agents like ibrutinib and lenalidomide appear to improve responses in these double-hit lymphomas [36].

\section{Treatment strategies}

There is still no standard of care for CD20 negative B cell lymphomas. Response to standard CHOP chemotherapy is inadequate. CODOX-M/IVAC (cyclophosphamide, vincristine, doxorubicin, methotrexate alternating with ifosfamide, etoposide, cytarabine) [37-44], doseadjusted $\mathrm{EPOCH}$ (infusional etoposide, vincristine and doxorubicin along with bolus cyclophosphamide and prednisone) [45-47], and HyperCVAD (cyclophosphamide, vincristine, doxorubicin and dexamethasone alternating with high-dose methotrexate and cytarabine) [48-52], are the suggested therapies. Upregulation of the expression of CD20 in CD20-negative B cell acute lymphoblastic leukemia following treatment with 5azacytidine has been reported [53]. In addition, good response to bortezomib in combination with infusional dose-adjusted EPOCH for the treatment of plasmablastic lymphoma has also been reported [54]. Upregulation of CD20 expression by epigenetic agents may be another option to re-sensitize B lymphoma to CD20 antibodies [55]. Plerixafor, a CXCR4 antagonist, has been shown to enhance rituximab-induced killing of lymphoma cells [56]. It would be interesting to examine whether plerixafor can have similar effect in CD20 negative lymphomas.

\section{Conclusion}

CD20 negative lymphoma is uncommon and has poor prognosis. It poses a diagnostic and therapeutic dilemma. Further studies need to be undertaken to establish the standard of care for this group of patients. Novel agents targeting B cell signalling pathways, such as, inhibitors of Bruton tyrosine kinase and phosphoinositol-3 kinase, may play important role in the therapy of this rare entity of $\mathrm{B}$ cell lymphomas [57-62]. PD-1 antibodies are active in lymphomas [63-65], it remains important to evaluate whether immune check point inhibitors have activity in CD20 negative lymphomas. Bcl-2 inhibitors may be another option for CD20 negative lymphomas and warrant further investigations $[34,66,67]$.

\section{Abbreviations}

CHOP: cyclophosphamide, doxorubicin, vincristine, and prednisone; CODOXM/IVAC: cyclophosphamide, vincristine, doxorubicin, methotrexate 
alternating with ifosfamide, etoposide, cytarabine; EPOCH: etoposide, vincristine and doxorubicin along with bolus cyclophosphamide and prednisone; HyperCVAD: cyclophosphamide, vincristine, doxorubicin and dexamethasone alternating with high-dose methotrexate and cytarabine; MoAb: monoclonal antibody

\section{Acknowledgement}

We are indebted to our families for their unconditional support.

\section{Funding}

There was no funding involved in this study.

\section{Availability of data and materials}

This is not applicable.

\section{Author's contributions}

DL designed the study. TK and DL drafted the manuscript. All authors involved in manuscript preparation and revisions. Both authors read and approved final manuscript.

\section{Competing interests}

The authors declare that they have no competing interests.

\section{Consent for publication}

This is not applicable.

\section{Ethics approval and consent to participate}

This is not applicable.

Received: 23 December 2016 Accepted: 3 February 2017 Published online: 07 February 2017

\section{References}

1. Tedder TF, Engel P. CD20: a regulator of cell-cycle progression of B lymphocytes. Immunol Today. 1994;15(9):450-4.

2. Cang S, Mukhi N, Wang K, Liu D. Novel CD20 monoclonal antibodies for lymphoma therapy. J Hematol Oncol. 2012;5:64.

3. Khandakar B, Wang W, Li S. Primary splenic red pulp diffuse large B-cell lymphoma with anaplastic features. Stem Cell Invest. 2016;3(4):9.

4. Liu Y, Zhang $X$, Zhong J-F. Current approaches and advance in mantle cell lymphoma treatment. Stem Cell Invest. 2015;2:18.

5. Mamorska-Dyga A, Ronny FMH, Puccio C, Islam H, Liu D. A rare case of the upper extremity diffuse large B-cell lymphoma mimicking soft tissue sarcoma in an elderly patient. Stem Cell Invest. 2016;3:25

6. Alduaij W, Illidge TM. The future of anti-CD20 monoclonal antibodies: are we making progress? Blood. 2011;117(11):2993-3001.

7. Alduaij W, Ivanov A, Honeychurch J, Cheadle EJ, Potluri S, Lim SH, Shimada K, Chan CH, Tutt A, Beers SA, Glennie MJ, Cragg MS, Illidge TM. Novel type II anti-CD20 monoclonal antibody (GA101) evokes homotypic adhesion and actin-dependent, lysosome-mediated cell death in B-cell malignancies. Blood. 2011:117(17):4519-29.

8. Coiffier B. Rituximab in diffuse large B-cell lymphoma. Clin Adv Hematol Oncol. 2004;2(3):156-7.

9. Coiffier B, Lepage E, Briere J, Herbrecht R, Tilly H, Bouabdallah R, Morel P, Van Den Neste E, Salles G, Gaulard P, Reyes F, Lederlin P, Gisselbrecht C. CHOP chemotherapy plus rituximab compared with $\mathrm{CHOP}$ alone in elderly patients with diffuse large-B-cell lymphoma. N Engl J Med. 2002;346(4):235-42.

10. Mayes S, Brown N, Illidge TM. New antibody drug treatments for lymphoma. Expert Opin Biol Ther. 2011;11(5):623-40.

11. Tiwari A, Ayello J, Van de ven C, Cairo MS. Effect of obinutuzumab (GA101), a type II glycoengineered monoclonal antibody targeting CD20, against rituximab resistant and sensitive cell lines in B-cell non-Hodgkin lymphoma. ASCO Meet Abstr. 2012;30(15_suppl)):e21150.

12. Umana P, Ekkehard M, Peter B, Gabriele K, Ursula P, Suter T, Grau R, Schmidt C, Herter S, Gerdes C, Nopora A, Patre M, Moser S, Sondermann P, Wheat L, Dyer MJS, Poppema S, Bauer S, Kubbies M, Strein P, Fertig G, Friess T, Dabbagh K, DalPorto J, Klein C. GA101, a novel humanized type II CD20 antibody with glycoengineered Fc and enhanced cell death induction, exhibits superior anti-tumor efficacy and superior tissue B cell depletion in vivo. ASH Annu Meet Abstr. 2007;110(11):2348.
13. van Meerten T, Hagenbeek A. CD20-targeted therapy: the next generation of antibodies. Semin Hematol. 2010;47(2):199-210.

14. Wierda WG, Kipps TJ, Mayer J, Stilgenbauer S, Williams CD, Hellmann A, Robak T, Furman RR, Hillmen P, Trneny M, Dyer MJS, Padmanabhan S, Piotrowska M, Kozak T, Chan G, Davis R, Losic N, Wilms J, Russell CA, Österborg A. Ofatumumab as single-agent CD20 immunotherapy in fludarabine-refractory chronic lymphocytic leukemia. J Clin Oncol. 2010;28(10):1749-55.

15. Wierda WG, Padmanabhan S, Chan GW, Gupta IV, Lisby S, Osterborg A, $\mathrm{Hx}$ CDSI. Ofatumumab is active in patients with fludarabine-refractory CLL irrespective of prior rituximab: results from the phase two international study. Blood. 2011;118(19):5126-9.

16. Gamonet C, Bole-Richard E, Delherme A, Aubin F, Toussirot E, GarnacheOttou F, Godet Y, Ysebaert L, Tournilhac O, Dartigeas C, Larosa F, Deconinck E, Saas P, Borg C, Deschamps M, Ferrand C. New CD20 alternative splice variants: molecular identification and differential expression within hematological B cell malignancies. Exp Hematol Oncol. 2016;5(1):7.

17. Wang K, Wei G, Liu D. CD19: a biomarker for B cell development, lymphoma diagnosis and therapy. Exp Hematol Oncol. 2012;1(1):36.

18. Armitage JO. A clinical evaluation of the international lymphoma study group classification of non-Hodgkin's lymphoma. The Non-Hodgkin's lymphoma classification project. Blood. 1997;89(11):3909-18.

19. Dong HY, Browne P, Liu Z, Gangi M. PAX-5 is invariably expressed in B-cell lymphomas without plasma cell differentiation. Histopathology. 2008;53(3):278-87.

20. Castillo JJ, Chavez JC, Hernandez-Ilizaliturri FJ, Montes-Moreno S. CD20negative diffuse large B-cell lymphomas: biology and emerging therapeutic options. Expert Rev Hematol. 2015;8(3):343-54.

21. Garg M, Lee BE, McGarry K, Mangray S, Castillo JJ. CD20-negative diffuse large B-cell lymphoma presenting with lactic acidosis. Am J Hematol. 2015:90(3):E49-50.

22. Castillo JJ, Furman M, Beltran BE, Bibas M, Bower M, Chen W, Diez-Martin JL, Liu JJ, Miranda RN, Montoto S, Nanaji NM, Navarro JT, Seegmiller AC, Vose JM. Human immunodeficiency virus-associated plasmablastic lymphoma: poor prognosis in the era of highly active antiretroviral therapy. Cancer. 2012;118(21):5270-7

23. Gaur S, Padilla O, Nahleh Z. Clinical features and prognosis of CD20 negative aggressive B-cell Non-hodgkins lymphoma. Lymphoma. 2013;2013:290585.

24. Castillo JJ, Shum H, Lahijani M, Winer ES, Butera JN. Prognosis in primary effusion lymphoma is associated with the number of body cavities involved. Leuk Lymphoma. 2012;53(12):2378-82.

25. Du MQ, Bacon CM, Isaacson PG. Kaposi sarcoma-associated herpesvirus/ human herpesvirus 8 and lymphoproliferative disorders. J Clin Pathol. 2007:60(12):1350-7.

26. Pan Z, Hu S, Li M, Zhou Y, Kim YS, Reddy V, Sanmann JN, Smith LM, Chen M, Gao Z, Wang HY, Yuan J. ALK-positive large B-cell lymphoma: a clinicopathologic study of 26 cases with review of additional 108 cases in the literature. Am J Surg Pathol. 2017:41(1):25-38.

27. De Paepe $P$, Baens $M$, van Krieken $H$, Verhasselt B, Stul M, Simons A, Poppe B, Laureys G, Brons P, Vandenberghe P, Speleman F, Praet M, De WolfPeeters C, Marynen P, Wlodarska I. ALK activation by the CLTC-ALK fusion is a recurrent event in large B-cell lymphoma. Blood. 2003;102(7):2638-41.

28. Chikatsu N, Kojima H, Suzukawa K, Shinagawa A, Nagasawa T, Ozawa H, Yamashita Y, Mori N. ALK+, CD30-, CD20- large B-cell lymphoma containing anaplastic lymphoma kinase (ALK) fused to clathrin heavy chain gene (CLTC). Mod Pathol. 2003;16(8):828-32.

29. Hiraga J, Tomita A, Sugimoto T, Shimada K, Ito M, Nakamura S, Kiyoi H, Kinoshita T, Naoe T. Down-regulation of CD20 expression in B-cell lymphoma cells after treatment with rituximab-containing combination chemotherapies: its prevalence and clinical significance. Blood. 2009;113(20):4885-93.

30. Matolcsy A, Chadburn A, Knowles DM. De novo CD5-positive and Richter's syndrome-associated diffuse large B cell lymphomas are genotypically distinct. Am J Pathol. 1995;147(1):207-16.

31. Lossos IS, Alizadeh AA, Diehn M, Warnke R, Thorstenson Y, Oefner PJ, Brown $P O$, Botstein D, Levy R. Transformation of follicular lymphoma to diffuse large-cell lymphoma: alternative patterns with increased or decreased expression of c-myc and its regulated genes. Proc Natl Acad Sci U S A. 2002;99(13):8886-91.

32. Browne $P$, Petrosyan $K$, Hernandez A, Chan JA. The B-cell transcription factors BSAP, Oct-2, and BOB.1 and the pan-B-cell markers CD20, CD22, and CD79a are useful in the differential diagnosis of classic Hodgkin lymphoma. Am J Clin Pathol. 2003;120(5):767-77. 
33. Narurkar R, Alkayem M, Liu D. SOX11 is a biomarker for cyclin D1-negative mantle cell lymphoma. Biomark Res. 2016;4(1):6.

34. Cang S, Iragavarapu C, Savooji J, Song Y, Liu D. ABT-199 (venetoclax) and $\mathrm{BCL}-2$ inhibitors in clinical development. J Hematol Oncol. 2015;8(1):129.

35. Cao Y, Yang G, Hunter ZR, Liu X, Xu L, Chen J, Tsakmaklis N, Hatjiharissi E, Kanan S, Davids MS, Castillo JJ, Treon SP. The BCL2 antagonist ABT-199 triggers apoptosis, and augments ibrutinib and idelalisib mediated cytotoxicity in CXCR4 wild-type and CXCR4 WHIM mutated waldenstrom macroglobulinaemia cells. Br J Haematol. 2015;170(1):134-8.

36. Younes A, Thieblemont C, Morschhauser F, Flinn I, Friedberg JW, Amorim S, Hivert B, Westin J, Vermeulen J, Bandyopadhyay N, de Vries R, Balasubramanian S, Hellemans P, Smit JW, Fourneau N, Oki Y. Combination of ibrutinib with rituximab, cyclophosphamide, doxorubicin, vincristine, and prednisone (R-CHOP) for treatment-naive patients with CD20-positive B-cell non-Hodgkin lymphoma: a non-randomised, phase 1b study. Lancet Oncol. 2014;15(9):1019-26.

37. Alwan F, He A, Montoto S, Kassam S, Mee M, Burns F, Edwards S, Wilson A, Tenant-Flowers M, Marcus R, Ardeshna KM, Bower M, Cwynarski K. Adding rituximab to CODOX-M/VAC chemotherapy in the treatment of HIVassociated Burkitt lymphoma is safe when used with concurrent combination antiretroviral therapy. AIDS. 2015;29(8):903-10.

38. Sun $H$, Savage K, Karsan A, Slack GW, Gascoyne RD, Toze CL, Sehn LH, Abou Mourad Y, Barnett MJ, Broady RC, Connors JM, Forrest DL, Gerrie AS, Hogge DE, Narayanan S, Nevill TJ, Nantel SH, Power MM, Sutherland HJ, Villa D, Shepherd JD, Song KW. Outcome of patients with Non-Hodgkin lymphomas with concurrent MYC and BCL2 rearrangements treated with CODOX-M/VAC with rituximab followed by hematopoietic stem cell transplantation. Clin Lymphoma Myeloma Leuk. 2015;15(6):341-8.

39. Evens AM, Carson KR, Kolesar J, Nabhan C, Helenowski I, Islam N, Jovanovic B, Barr PM, Caimi PF, Gregory SA, Gordon LI. A multicenter phase II study incorporating high-dose rituximab and liposomal doxorubicin into the CODOX-M/IVAC regimen for untreated Burkitt's lymphoma. Ann Oncol. 2013;24(12):3076-81.

40. Rodrigo JA, Hicks LK, Cheung MC, Song KW, Ezzat H, Leger CS, Boro J, Montaner JS, Harris M, Leitch HA. HIV-associated Burkitt lymphoma: good efficacy and tolerance of intensive chemotherapy including CODOX-M/IVAC with or without rituximab in the HAART Era. Adv Hematol. 2012;2012: 735392.

41. Corazzelli G, Frigeri F, Russo F, Frairia C, Arcamone M, Esposito G, De Chiara A, Morelli E, Capobianco G, Becchimanzi C, Volzone F, Saggese M, Marcacci G, De Filippi R, Vitolo U, Pinto A. RD-CODOX-M/IVAC with rituximab and intrathecal liposomal cytarabine in adult Burkitt lymphoma and 'unclassifiable' highly aggressive B-cell lymphoma. Br J Haematol. 2012; 156(2):234-44.

42. Barnes JA, Lacasce AS, Feng Y, Toomey CE, Neuberg D, Michaelson JS, Hochberg EP, Abramson JS. Evaluation of the addition of rituximab to CODOX-M/VAC for Burkitt's lymphoma: a retrospective analysis. Ann Oncol. 2011;22(8):1859-64.

43. Mead GM, Barrans SL, Qian W, Walewski J, Radford JA, Wolf M, Clawson SM, Stenning SP, Yule CL, Jack AS, UKNCRILCS Group, Australasian L, Lymphoma G. A prospective clinicopathologic study of dose-modified CODOX-M/IVAC in patients with sporadic Burkitt lymphoma defined using cytogenetic and immunophenotypic criteria (MRC/NCRI LY10 trial). Blood. 2008;112(6):2248-60.

44. Davidson KL, Devaney MB, Tighe JE, Rogers SY, Dunlop DJ, Mackie MJ, Thomas RV, Johnson PR, Scotland and Newcastle Lymphoma Group Study. A pilot study of CODOX-M/IVAC in primary refractory or relapsed highgrade non-Hodgkin's lymphoma. A Scotland and Newcastle lymphoma group study. Haematologica. 2003;88(12):1366-71.

45. Dunleavy K, Pittaluga S, Shovlin M, Roschewski M, Lai C, Steinberg SM, Jaffe ES, Wilson WH. Phase II trial of dose-adjusted EPOCH in untreated systemic anaplastic large cell lymphoma. Haematologica. 2016;101(1):e27-29.

46. Purroy N, Bergua J, Gallur L, Prieto J, Lopez LA, Sancho JM, Garcia-Marco JA, Castellvi J, Montes-Moreno S, Batlle A, de Villambrosia SG, Carnicero F, Ferrando-Lamana L, Piris MA, Lopez A. Long-term follow-up of doseadjusted EPOCH plus rituximab (DA-EPOCH-R) in untreated patients with poor prognosis large B-cell lymphoma. A phase II study conducted by the spanish PETHEMA group. Br J Haematol. 2015;169(2):188-98.

47. Dunleavy K, Pittaluga S, Maeda LS, Advani R, Chen CC, Hessler J, Steinberg SM, Grant C, Wright G, Varma G, Staudt LM, Jaffe ES, Wilson WH. Dose- adjusted EPOCH-rituximab therapy in primary mediastinal B-cell lymphoma. N Engl J Med. 2013;368(15):1408-16.

48. Linder K, Gandhiraj D, Hanmantgad M, Seiter K, Liu D. Complete remission after single agent blinatumomab in a patient with pre-B acute lymphoid leukemia relapsed and refractory to three prior regimens: hyperCVAD, high dose cytarabine mitoxantrone and CLAG. Exp Hematol Oncol. 2015;5:20.

49. Saste A, Arias-Stella J, Kuriakose P. Progression of a hepatosplenic gamma delta T-cell leukemia/lymphoma on hyperCVAD/MTX and ara-C: literature review and our institutional treatment approach. Clin Case Rep. 2016;4(1):67-71.

50. Daver N, Boumber Y, Kantarjian H, Ravandi F, Cortes J, Rytting ME, Kawedia JD, Basnett J, Culotta KS, Zeng Z, Lu H, Richie MA, Garris R, Xiao L, Liu W, Baggerly KA, Jabbour E, O'Brien S, Burger J, Bendall $\amalg$, Thomas D, Konopleva M. A phase $1 / I l$ study of the mTOR inhibitor everolimus in combination with HyperCVAD chemotherapy in patients with relapsed/refractory acute lymphoblastic leukemia. Clin Cancer Res. 2015;21(12):2704-14.

51. Romaguera JE, Fayad LE, Feng L, Hartig K, Weaver $P$, Rodriguez MA, Hagemeister FB, Pro B, McLaughlin P, Younes A, Samaniego F, Goy A, Cabanillas F, Kantarjian H, Kwak L, Wang M. Ten-year follow-up after intense chemoimmunotherapy with Rituximab-HyperCVAD alternating with Rituximab-high dose methotrexate/cytarabine (R-MA) and without stem cell transplantation in patients with untreated aggressive mantle cell Iymphoma. Br J Haematol. 2010;150(2):200-8.

52. Dimopoulos MA, Weber D, Kantarjian $H$, Delasalle KB, Alexanian $\mathrm{R}$. HyperCVAD for VAD-resistant multiple myeloma. Am J Hematol. 1996;52(2):77-81.

53. Rahme R, Benayoun E, Pautas C, Cordonnier C, Wagner-Ballon O, Maury S. Treatment with 5-azacytidin upregulates the expression of CD20 in CD20negative B cell acute lymphoblastic leukemia: a case report. Exp Hematol. 2013:41(6):505-7.

54. Castillo JJ, Reagan JL, Sikov WM, Winer ES. Bortezomib in combination with infusional dose-adjusted EPOCH for the treatment of plasmablastic lymphoma. Br J Haematol. 2015;169(3):352-5.

55. Damm JK, Gordon S, Ehinger M, Jerkeman M, Gullberg U, Hultquist A, Drott K. Pharmacologically relevant doses of valproate upregulate CD20 expression in three diffuse large B-cell lymphoma patients in vivo. Exp Hematol Oncol. 2015;4(1):4

56. Reinholdt L, Laursen MB, Schmitz A, Bødker JS, Jakobsen LH, Bøgsted M, Johnsen HE, Dybkær K. The CXCR4 antagonist plerixafor enhances the effect of rituximab in diffuse large B-cell lymphoma cell lines. Biomark Res. 2016;4(1):12.

57. Treon SP, Tripsas CK, Meid K, Warren D, Varma G, Green R, Argyropoulos KV, Yang G, Cao Y, Xu L, Patterson CJ, Rodig S, Zehnder JL, Aster JC, Harris NL, Kanan S, Ghobrial I, Castillo JJ, Laubach JP, Hunter ZR, Salman Z, Li J, Cheng M, Clow F, Graef T, Palomba ML, Advani RH. Ibrutinib in previously treated Waldenstrom's macroglobulinemia. N Engl J Med. 2015;372(15):1430-40.

58. Wu J, Liu C, Tsui ST, Liu D. Second-generation inhibitors of Bruton tyrosine kinase. J Hematol Oncol. 2016;9:80.

59. Wu J, Zhang M, Liu D. Acalabrutinib (ACP-196): a selective secondgeneration BTK inhibitor. J Hematol Oncol. 2016;9(1):21.

60. Wu J, Zhang M, Liu D. Bruton tyrosine kinase inhibitor ONO/GS-4059: from bench to bedside. Oncotarget. 2017;8:7201-7208.

61. Rai KR. Therapeutic potential of new B cell-targeted agents in the treatment of elderly and unfit patients with chronic lymphocytic leukemia. J Hematol Oncol. 2015;8:85.

62. Rai KR, Barrientos JC. Movement toward optimization of CLL therapy. N Engl J Med. 2014;370(12):1160-2.

63. Bi X-w, Wang H, Zhang W-w, Wang J-h, Liu W-j, Xia Z-j, Huang H-q, Jiang W-q, Zhang Y-j, Wang L. PD-L1 is upregulated by EBV-driven LMP1 through $\mathrm{NF}-\mathrm{kB}$ pathway and correlates with poor prognosis in natural killer/T-cell lymphoma. J Hematol Oncol. 2016;9(1):109.

64. Shi L, Chen S, Yang L, Li Y. The role of PD-1 and PD-L1 in T-cell immune suppression in patients with hematological malignancies. J Hematol Oncol. 2013;6(1):74.

65. Ansell SM, Lesokhin AM, Borrello I, Halwani A, Scott EC, Gutierrez M, Schuster SJ, Millenson MM, Cattry D, Freeman GJ, Rodig SJ, Chapuy B, Ligon AH, Zhu L, Grosso JF, Kim SY, Timmerman JM, Shipp MA, Armand P. PD-1 blockade with nivolumab in relapsed or refractory Hodgkin's lymphoma. N Engl J Med. 2015;372(4):311-9.

66. Roberts AW, Davids MS, Pagel JM, Kahl BS, Puvvada SD, Gerecitano JF, Kipps TJ, Anderson MA, Brown JR, Gressick L, Wong S, Dunbar M, Zhu M, Desai 
MB, Cerri E, Heitner Enschede S, Humerickhouse RA, Wierda WG, Seymour JF. Targeting BCL2 with venetoclax in relapsed chronic lymphocytic leukemia. N Engl J Med. 2016;374(4):311-22.

67. Souers AJ, Leverson JD, Boghaert ER, Ackler SL, Catron ND, Chen J, Dayton BD, Ding H, Enschede SH, Fairbrother WJ, Huang DC, Hymowitz SG, Jin S, Khaw SL, Kovar PJ, Lam LT, Lee J, Maecker HL, Marsh KC, Mason KD, Mitten MJ, Nimmer PM, Oleksijew A, Park CH, Park CM, Phillips DC, Roberts AW, Sampath D, Seymour JF, Smith ML, et al. ABT-199, a potent and selective BCL-2 inhibitor, achieves antitumor activity while sparing platelets. Nat Med. 2013;19(2):202-8.

Submit your next manuscript to BioMed Central and we will help you at every step:

- We accept pre-submission inquiries

- Our selector tool helps you to find the most relevant journal

- We provide round the clock customer support

- Convenient online submission

- Thorough peer review

- Inclusion in PubMed and all major indexing services

- Maximum visibility for your research

Submit your manuscript at www.biomedcentral.com/submit 